\title{
Experimental investigations of wooden and concrete composite beams subject to long-term load
}

\author{
Mariusz Czabak*, and Zbigniew Perkowski \\ Opole University of Technology, Faculty of Civil Engineering and Architecture, Katowicka 48, \\ 45-061 Opole, Poland
}

\begin{abstract}
The issue of reinforcing wooden beams via their joining with a concrete upper slab is still being widely discussed in the literature of the problem. The paper is an extended version of the authors' previous research conducted in this subject matter for short-term static loads. The current work takes into account also a qualitative assessment of two-year behaviour of the structure based on the measurements of its creep, temperature and relative humidity of the ambient air in typical in-door conditions. The beams were $4-\mathrm{m}$ long and subject to a total load of $10 \mathrm{kN}$. Their layers had crosssectional dimensions equal to $95 \mathrm{~mm} \times 195 \mathrm{~mm}$ and $300 \mathrm{~mm} \times 50 \mathrm{~mm}$ for the wooden rib and reinforced concrete upper slab, respectively.
\end{abstract}

\section{Introduction}

Technical issues related to the broadly understood industry, including construction, both with regard to the erection and modernization of buildings, are increasingly focused on the economisation of newly introduced or already well-known structural systems. In the economic calculation of the building projects, the environmental aspect must be considered at the same time, the needs of which can be most effectively satisfied by limiting the consumption of energy. Hence, in the case of many construction branches, changes are observed consisting in the increasingly common use of recycled materials or from renewable sources, such as wood. In order to increase the material consumption savings, more and more advanced and accurate calculation models of the structure are being introduced. However, in order to use any new approach in the industry in general, be it on the side of model calculations or material solutions, apart from the theses behind it, it must be verified in real conditions, providing sufficient confirmation of its safe use. In the case of the limit states assessment of atypical building structures, only the performance of the experiment on a real scale or similar to it allows for the final reliable verification of their behavior from the point of view of the safety of use.

Guided by these premises, the authors will present the research methodology and preliminary results of the experiment of long-term loading of wooden and concrete composite beams in this paper. The starting point for their implementation was the research of authors

Corresponding author: m.czabak@po.opole.pl 
published among others in [1], where short-term tests of such elements are described, with an indication of the necessity of further testing due to the visible initiation of the creep process already observed in this case. A coefficient inverse problem to the determination of initial elastic properties of a wooden and concrete composite beam was also formulated therein.

The issue of reinforcing wooden beams by joining them with an upper concrete slab is still being widely discussed in literature (e.g. [2-4]). There are also few studies similar to those presented by the authors of this work, such as [5-7], where long-term wooden and concrete composite beams were tested, as well as a proposal to describe the theoretical behavior of this type of systems [8]. Experimental measurements of this type still require solving many problems posed by their nature, such as, e.g. long-term data acquisition, the method of long-term loading, assessment of the influence of microclimate prevailing in the surroundings of the test stand (temperature and humidity), etc. In this paper, the authors, unlike other works of this type, also attempted to archive the time courses of the curvatures of the axes of wooden and concrete beam layers in creep conditions, and also proposed a convenient method of loading beams using water tanks from the point of view of the construction of the measuring station.

\section{Description of beam constituent materials}

The most important aspect of joining two different materials in the structure is the optimal use of their strength characteristics - in the case analyzed for concrete, compressive strength, and for wood, tensile strength (Fig. 1).

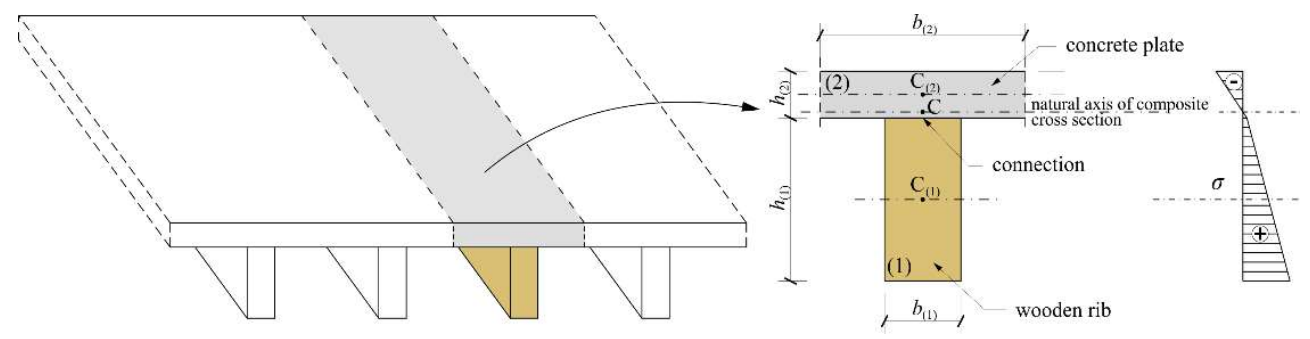

Fig. 1. Scheme of a wooden and concrete composite ceiling with its rib and optimal distribution of cross-sectional normal stresses in the physically linear range.

\subsection{Wood}

As is known, wood is a material of biological origin. This carries certain limitations. While nowadays, it is not a problem to create environmentally friendly crops for the needs of the industry, including construction, tree growth is a long-term process; it is complex and dependent on external factors such as weather, soil and water conditions or location relative to other plants and obstacles limiting access to sunlight. The variability of the environment significantly affects the heterogeneity of the structure and uneven spatial distribution of material parameters of wood raw material, hence 4 pine-wood beams (approx. C20 class) not originating from one batch of material were specially used in the research. The initial crosssection was $10 \times 20 \mathrm{~cm}$, while due to the loss of moisture and consequently, shrinkage, the average section decreased to $9.5 \times 19.5 \mathrm{~cm}$. In addition, in a temperate climate, the tree grows only during the vegetative period, that is from spring (early wood growth) to late autumn (late wood growth) and its cells, due to its vegetative functions, have an elongated shape. Thus, when analyzing the inhomogeneity of wood, one should take into account its orthotropy, i.e. the dependence of its physical (including mechanical) properties on the 
direction of its fibers. Due to the micro-wood structure, the most favorable strength parameters may be observed along the fibers. In addition, the cellulose that essentially forms wood fibers is a biopolymer. That is why the material has rheological features, i.e. it is subject to creep, the mechanism of which in this case can be visualized as deformations that progress over time as a result of unraveling and elongation of subsequent threads of cellulose particles (Fig. 2). This process also proceeds with varying intensity depending on whether there are water molecules in the surroundings of the cellulose chains.

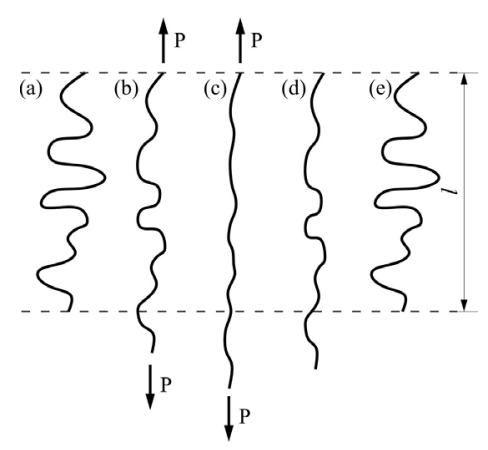

Fig. 2. Rheology in the behavior of polymer fibers a) initial shape b) stretching stage c) reaching maximum elongation d) unloading stage e) return to the initial shape.

According to the PN-EN 1995-1-1 standard, the final deflection of a wooden element due to its rheological properties and moisture content can constitute from 1.6 to 3 times more than the value of instantaneous deflection in typical operating conditions.

\subsection{Concrete}

Concrete is a material the parameters of which strongly depend on its recipe. In comparison to wood, it is more homogeneous, isotropic and predictable, in particular in the case of compressive strength, if appropriate technological regimes are maintained. The concrete used in the experiment, based on the conducted strength tests, achieved a mean compression strength of $\sim 42 \mathrm{MPa}$ after 28 days. The poured over slab, simulating a ceiling section in the study, was 50-mm thick and 300-mm wide.

Similarly, to wood, concrete also exhibits rheological properties, where the creep process can be explained by the fact that the crystalline hydrates of cement components are partially separated by layers of porous liquid, which, by limiting friction, allows their movement relative to each other in a limited manner. In addition, when the concrete element can dry out, moisture exchange between its gel and capillary pores also intensifies creep [9]. For example according to the PN-EN 1992-1-1 standard, the final value of the creep strain increment for concrete elements loaded after 28 and subject to typical in-door conditions can be even 2.3 times higher than the instantaneous strain in case of concrete strength class $\mathrm{C} 35 / 45$ and notional size of element cross-section $h_{0}=100 \mathrm{~mm}$.

\subsection{Combination of beam layers}

The combination of both layers of the beam, as in the case of previous tests conducted by the authors with static short-term loads [1], was ensured by using SK 8,0x100/60/10 steel wood screws, and their penetration and placement was selected according to the requirements of PN-EN 1995-1-1 (Fig. 3). In general, the temporary shear stiffness of the joint and its rheological characteristics, due to its construction, can be assumed as the resultant stiffness 
of the connectors' steel and materials in the immediate vicinity of the connector (in the concrete and wooden layer).

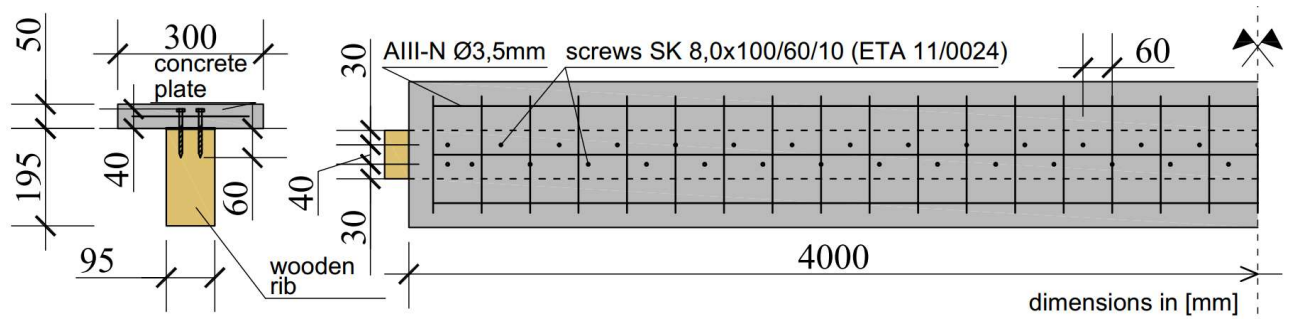

Fig. 3. Cross-section and top view of the tested beams.

\section{Test stand}

The test stand in total consists of two systems with two beams each, which in effect allows independent testing of 4 elements at the same time using only two loading tanks. The static scheme assumed a system of simply supported beams loaded with two symmetrical concentrated forces (four-point bending) (Fig. 5). Source literature includes various ways of loading systems for study of creep, such as steel elements [7,8] or buckets with water [5]; whereby such a solution prevents uniform and even load increase in the first stage of the experiment or its convenient implementation. The solution may be tanks used for the purposes of this work, which can be filled with water, increasing the load linearly in time in a static manner. The value of the maximum load was assumed in the vicinity of $15 \%$ of the load capacity of beams estimated on the basis of studies from [1]. The tanks were based on a system of articulated beams concentrating force in two points of beams.
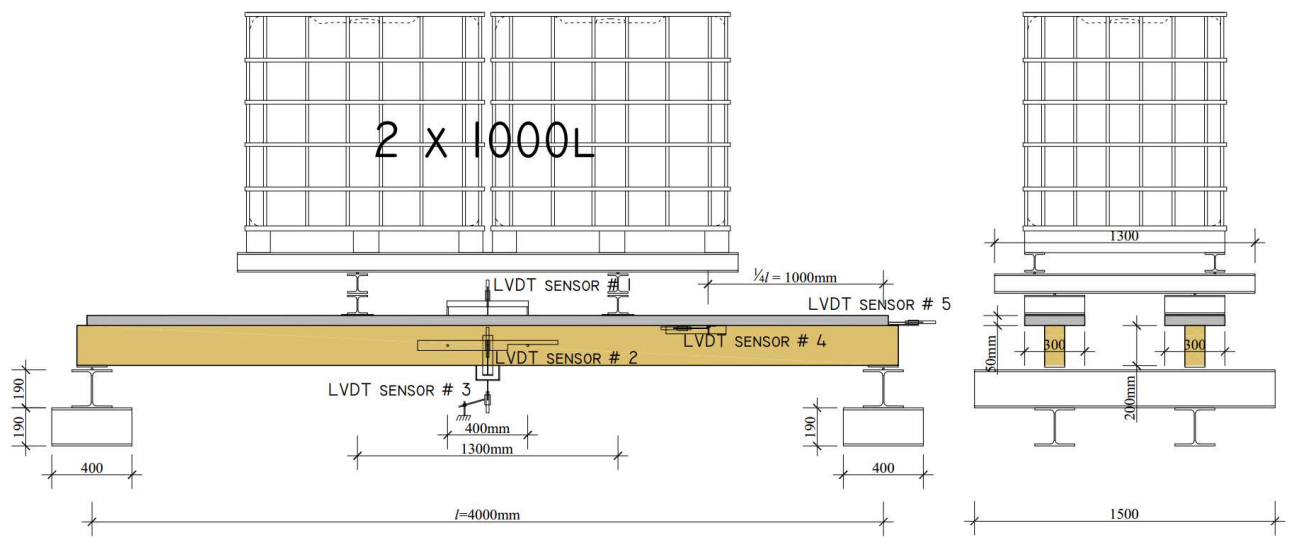

Fig. 5. Side view and cross-section of a single test stand.

\subsection{Measurements and acquisition of data}

Each composite beam has been equipped with 5 inductive displacement sensors (LVDT), according to Fig. 5. Sensor \# 1 measured the curvature of the concrete element (Fig. 6a), a sensor \# 2 measured the curvature of the wooden element (Fig. 6b) using handles with a $400-\mathrm{mm}$ measuring base constructed for the needs of the experiment. The value of the curvature of the $i$-th layer was calculated for the middle sections of the beams as per dependence: 


$$
\kappa_{i}=1 / \rho_{i}=\frac{2 f_{i}}{f_{i}^{2}+\left(\frac{l_{i}}{2}\right)^{2}}
$$

where: $\kappa_{i}$ - curvature of layer $i, \rho_{i}$ - radius of curvature of layer $i, l_{i}$ - length of the device's measurement base in layer $i, f_{i}$ - measured value of vertical displacements in the middle of the inclinometer on layer $i$.

Sensor \# 3 allowed to measure the deflection in the middle of the beam span (Fig. 6c), while \# 4 and \# 5, respectively measured inter-layer slip in $1 / 4$ of the beam span and at the end of the element (Figs. 6e and 6d).

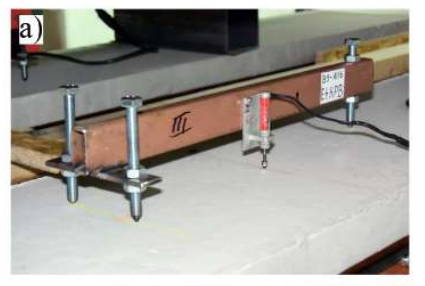

b)

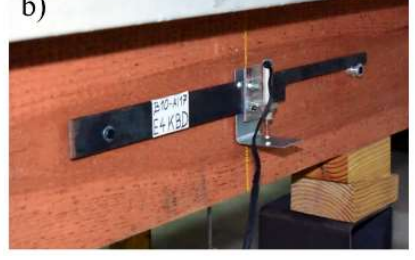

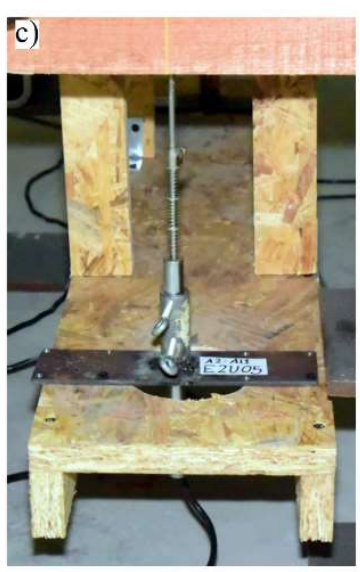
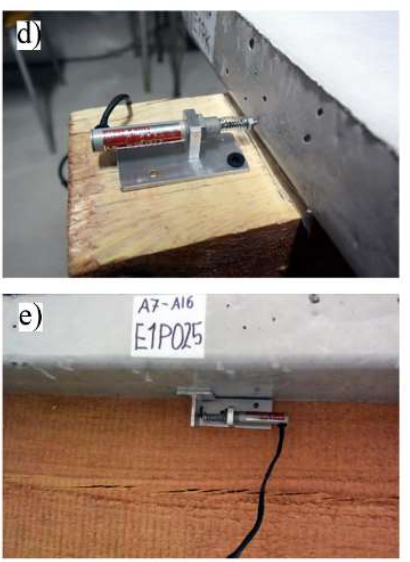

Fig. 6. Photos of the methods of assembly and construction of LVDT sensors.

In addition, due to the sensitivity of beam materials to environmental conditions (including moisture-induced shrinkage and swelling, change in creep intensity due to humidity change), the temperature and relative humidity of the air in the room with the stand were measured using hytherograph LAB-EL LB-525. For this reason, it should also be mentioned that the measuring station was located in a closed room of the Structural Engineering Laboratory at the Faculty of Civil Engineering and Architecture of the Opole University of Technology, where central heating was switched on during the winter months.

\subsubsection{Data acquisition}

The use of inductive displacement sensors implies the need to build a measurement path adapted to the needs of their operation (Fig. 7). Inductive sensors were powered by a Peltron MPL512 conditioner generating variable voltage of $5 \mathrm{kHz}$ to power the coil. Then as a result of moving the sensor core, there is a proportional voltage change at its output. The conditioner straightens the received AC signal to DC and amplifies it to a maximum of $\pm 10 \mathrm{~V}$.

Another important element of the measurement path is the data acquisition card. In this case, NI USB-6218 was used, which allows the analog voltage information to be converted into digital values. Finally, the digital signal is processed by the computer with the LabVIEW SignalExpress software allowing to calibrate each of the channels so that the measured voltages are converted into corresponding displacements (taking into account the nonlinearity and individual character of each sensor) and collect data strings stored as vectors. 


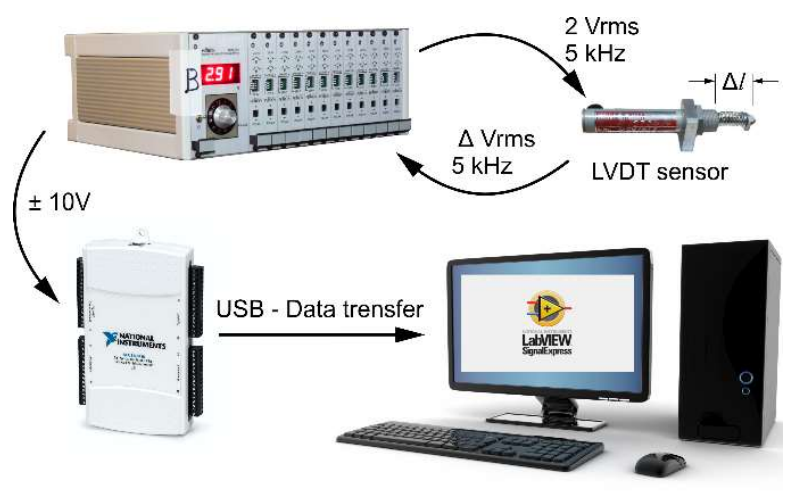

Fig. 7. Diagram of sensor supply and data acquisition.

A single displacement measurement made by each sensor took place every one second, while the data collected constituted the average value over a period of 60 seconds. This treatment allowed to some extent to limit the amount of collected data, and more importantly, reduce the measurement noise. From the moment of applying the load (filling the tanks with water in 26-08-2015) to the moment of collecting data presented in the article (29-09-2017), a period of 2 years has passed. Finally, over 24 million pieces of data were collected in this period, along with the values of temperature and relative humidity of the air, which were also registered every 60 seconds.

\section{Measurement results}

At the same time, data from four composite beams was collected. Their arrangement and numbering are presented in Fig. 8. Accordingly, the beams \# 1 and \# 2, as well as \# 3 and \# 4 are positioned in pairs under loading water tanks as in Fig. 5.

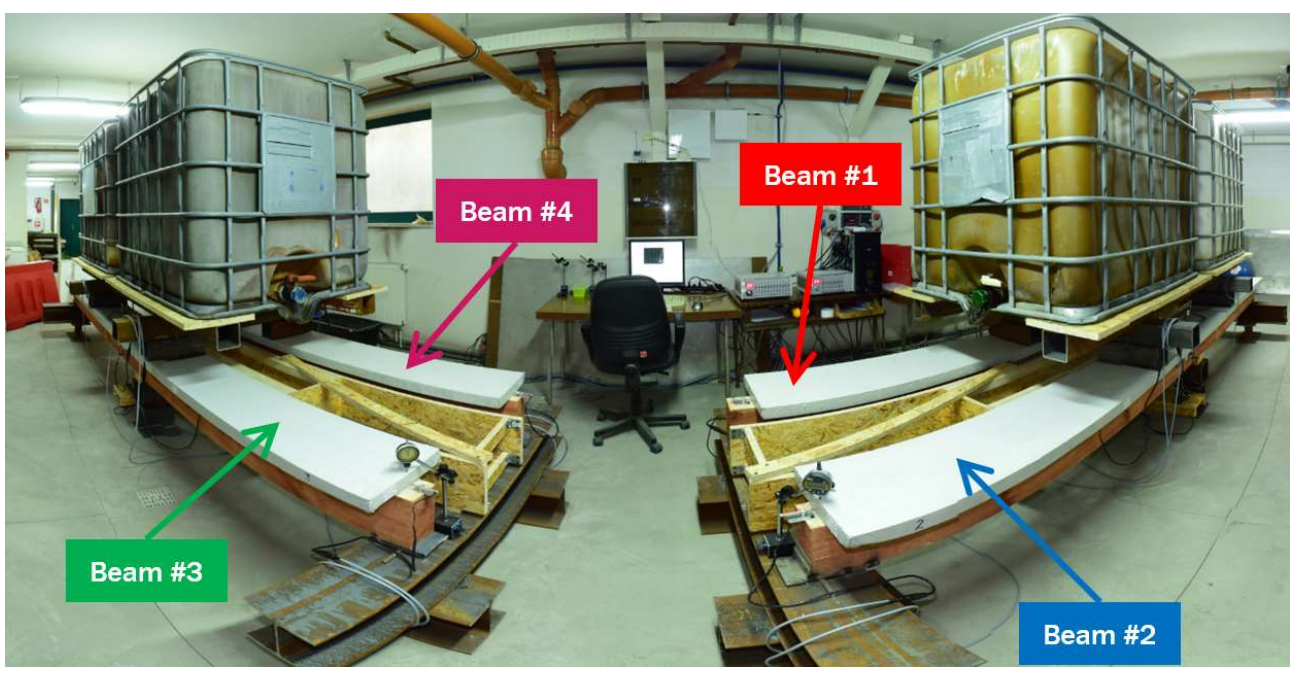

Fig. 8. Photo of a test stand with numeration of beams. 


\subsection{Deflection}

The results from Fig. 9 present the values of deflections in the middle of the span for all beams comparatively with measurements of relative humidity and temperature of the ambient air. It can be observed that despite the passage of more than two years in the laboratory conditions with the natural changes in relative humidity and relatively constant temperature, the creeping process is still progressing slightly (compared, e.g. to maximum deflections in summer 2016 and 2017). In addition, the registered humidity fluctuations have a significant impact on the amount of deflection compared to deflections coming only from the mechanical load.

In the spring to autumn season, due to the features of the climate prevailing in Poland, there occurs a natural increase in the relative humidity of the air, and thus acceleration of creeping processes in the constituent materials, as well as their swelling. The opposite effect is observed in the period from autumn to spring (in the heating period) where the beams, as a result of shrinkage, are subject to partial straightening. It is only on beam \#4 that the process opposite to the previously described one becomes visible. The reason for the differences in the load of beams as a result of various deflections of beams \# 3 and \# 4 was rejected, as this difference generates only $1 \%$ of the water level in tanks. Therefore, the most probable cause remains the large heterogeneity of hygroscopic features of wood along the height of individual ribs of wooden composite beams.

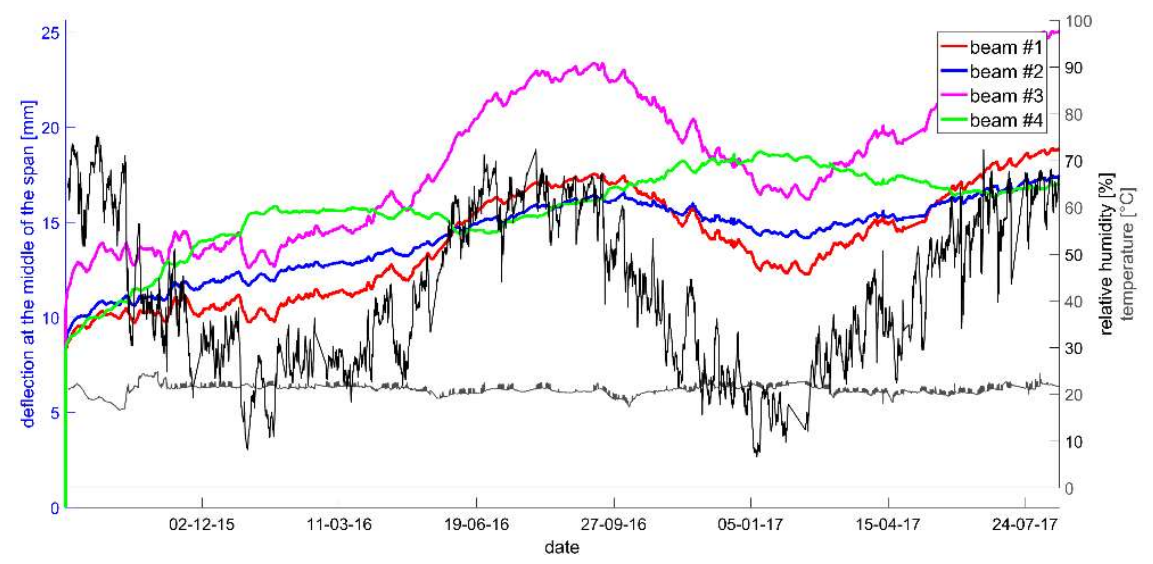

Fig. 9. Courses of deflections in the middle of the beam span compared with the relative humidity and temperature of the ambient air.

\subsection{Slip}

Fig. 10 presents inter-layer slip of beams in $1 / 4$ of their span and over their supports, together with the measurements of relative humidity and temperature of the ambient air. Analyzing the results from graphs (Fig. 10) one may observe, similar as in the case of deflections, tendencies of a significant impact of changes in system humidity on the values of slip. In addition, slip at the end of the beam is much more sensitive to changes in humidity in short periods of time than in $1 / 4$ of its span. This fact results from the location of sensor \# 5 in the place where the cross-sectional area of the wood was exposed. There, moisture sorption/desorption occurred much faster than in the case of a tangent and radial surfaces [11]. In connection with this process and the method of assembly of sensors, the slip measurements had to be partially disturbed by moisture-induced cracking of wood along the fibers (visible e.g. in Fig. 6e), which began and stabilized during the first heating period. The 
authors relate the indications of slip sensors (\# 5) from beams \# 1, \# 2 and \# 4 with this phenomenon, where on average, despite visible creeping, they did not increase or decrease.

a)

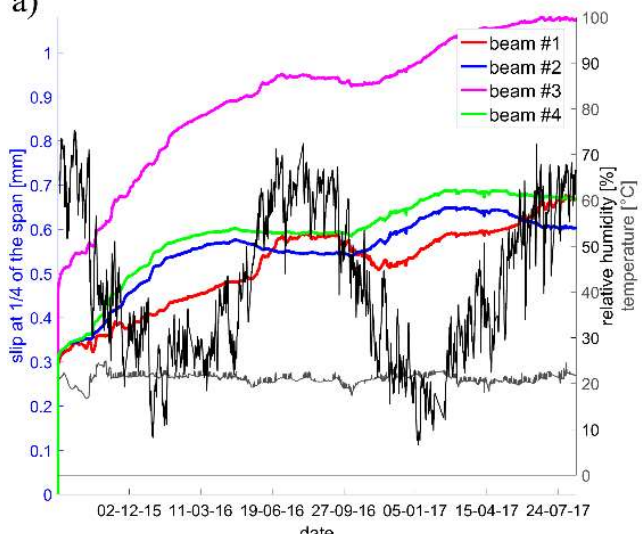

b)

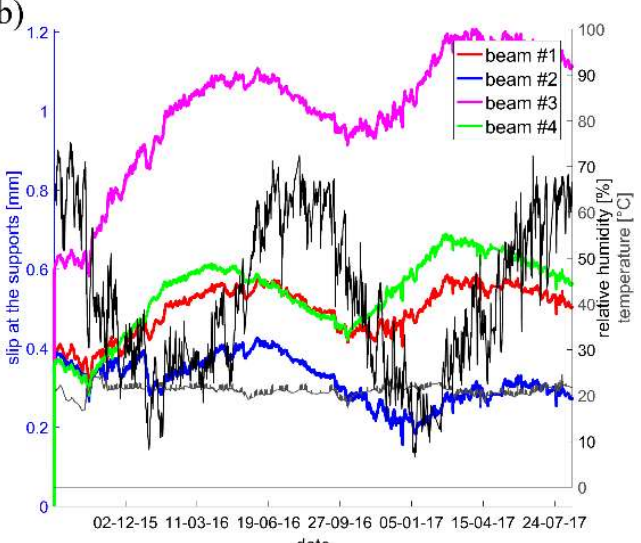

date

Fig. 10. Slippage patterns in $1 / 4$ span (a) and over supports (b) of beam compared with the relative humidity and temperature of the ambient air.

\subsection{Curvatures}

The four-point bending scheme, thanks to the section with a constant bending moment in the central section of the beam, allows for a convenient measurement of the curvature of layers [1]. Damage to the wood structure, already signaled in point 4.2 and resulting from its cracking during drying, caused that the measurement method established at the beginning of the research made the curvature of wooden rib impossible to use to assess wood rheological processes in the long term.
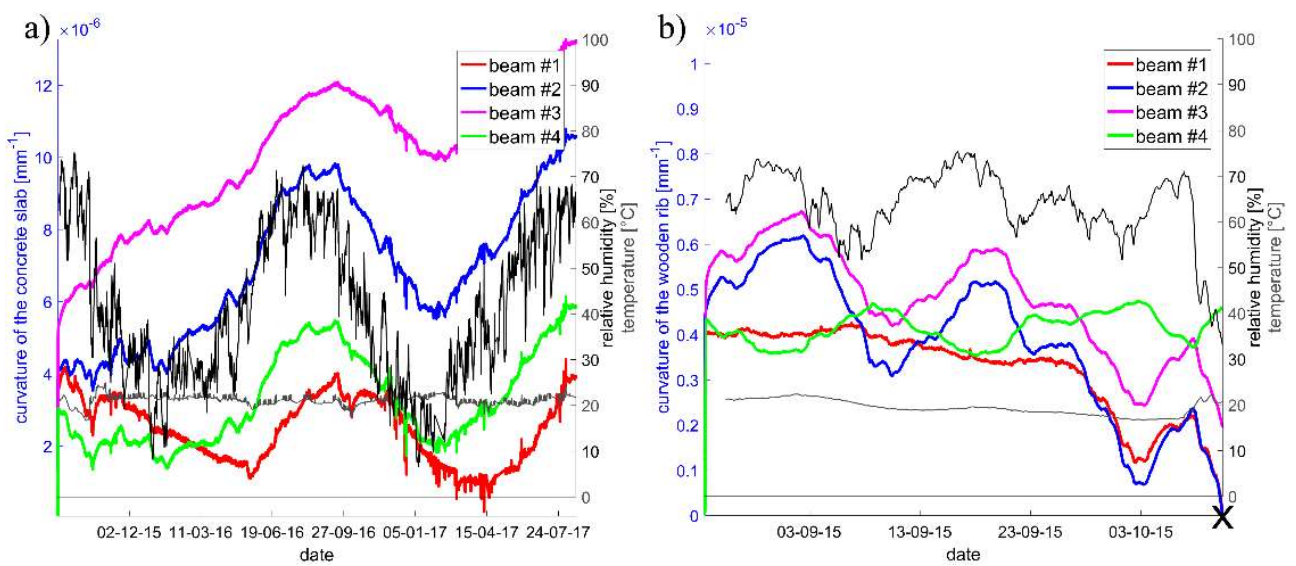

Fig. 11. The curvature courses of the axis of layers (upper concrete slab (a) and wooden rib (b)) in the middle of the beam span compared with the relative humidity and temperature of the ambient air.

Hence, in Fig. 11b, only measurements from the first month of the study are presented in this case. On the other hand, these measurements for the upper concrete plate (Fig. 11a) were not disturbed this way. They show on average in case of beams \# 1 and 4 a constant or decreasing tendency in curvatures and, oppositely, for beams \# 2 and 3 . This diversity results also from the inhomogeneity of the wood structure and for beams \# 1 and 4, it indicates the intense process of pulling the connectors out of the wood rib in its middle section as a result of 
creeping. In beams \# 2 and 3 this process is not so intense and indicates the occurrence in the upper part of wooden ribs of wood with higher stiffness.

\section{Parameters defining the initial stiffness of the beams}

The Young's modulus of concrete used in the tested beams was estimated using ultrasonic tests based on measuring the velocity of the longitudinal wave across the upper slab. The average wave speed of $125 \mathrm{kHz}$ frequency for beams \# 1 - \# 4, respectively, amounted to: $4167 \mathrm{~m} / \mathrm{s}, 3960 \mathrm{~m} / \mathrm{s}, 3946 \mathrm{~m} / \mathrm{s}$ and $3940 \mathrm{~m} / \mathrm{s}$, which allowed to determine the dynamic modulus of elasticity from the formula:

$$
E_{\mathrm{cd}}=\rho_{c} c_{\mathrm{P}}{ }^{2} \frac{(1+v)(1-2 v)}{(1-v)}
$$

where: $E_{\mathrm{cd}}$ - dynamic Young's modulus [Pa], $\rho_{c}$ - density of concrete $[\mathrm{kg} / \mathrm{m} 3]$ (equal to 2285 $\left.\mathrm{kg} / \mathrm{m}^{3}\right), c_{\mathrm{P}}-$ speed of longitudinal waves [m/s], $v$ - Poisson's ratio [-] (assumed as equal to 0.2 ). In this way, it was deducted that $E_{\text {cd }}$ averaged per the volume of concrete slabs of \# 1 - \# 4 beams amounted to, respectively: $35.71 \mathrm{GPa}, 32.25 \mathrm{GPa}, 32.02 \mathrm{GPa}$ and $31.92 \mathrm{GPa}$.

The estimated value of the static modulus of elasticity can be determined on the basis of the equations collected in $[9,12]$, whereby $E_{\mathrm{cd}}$ is expressed in [GPa]:

$$
E_{\mathrm{c}}{ }^{\prime}=0.83 E_{c d}, E_{\mathrm{c}}{ }^{\prime \prime}=1.25 E_{c d}-19 \text { or } E_{\mathrm{c}}{ }^{\prime \prime \prime}=E_{c d}-5.864
$$

For example, depending on the formula adopted, the static elastic modulus for concrete in beam $\# 1$ amounts to, respectively: $E_{\mathrm{c}}{ }^{\prime}=29.64 \mathrm{GPa},{E_{\mathrm{c}}}{ }^{\prime \prime}=25.64 \mathrm{GPa}$ and: $E_{\mathrm{c}}{ }^{\prime \prime}=29.85 \mathrm{GPa}$. In turn, by correlating Young's modulus of concrete with its strength according to the relation from work [9]

$$
E_{c}=4,73\left(f_{c}\right)^{0,5}
$$

it amounts to $30.65 \mathrm{GPa}$. Based on the obtained results, it can be initially concluded that the estimation of Young's modulus averaged for the concrete slab of beams by means of longitudinal velocity measurements of ultrasonic waves according to the described method is correct in practical conditions.

Solving further the system of differential equations describing displacements in composite beams presented, among others, in [13] and posing inverse problem on its basis, consisting in minimizing the differences between the values of the model and measurement data (the initial deflections, curvatures and slips), it is possible to estimate the initial Young's modulus for wood $E_{\mathrm{w}}$ and shear stiffness of the joint $k$. On this basis, the following values have been determined for beams \# 1, \#2, \# 3 and \# 4, respectively:

$$
\begin{aligned}
& \# 1: E_{\mathrm{w}}=9.37 \mathrm{GPa}, k=70.92(\mathrm{MN} / \mathrm{m}) / \mathrm{m}, \quad \# 2: E_{\mathrm{w}}=8.24 \mathrm{GPa}, k=70.67(\mathrm{MN} / \mathrm{m}) / \mathrm{m} \\
& \# 3: E_{\mathrm{w}}=8.84 \mathrm{GPa}, k=39.48(\mathrm{MN} / \mathrm{m}) / \mathrm{m}, \quad \# 4: E_{\mathrm{w}}=9.08 \mathrm{GPa}, k=71.00(\mathrm{MN} / \mathrm{m}) / \mathrm{m}
\end{aligned}
$$

The above results show relatively similar values of the modulus of elasticity for the pine wood and concrete used in each of the beams. In the case of shear stiffness of the joint, differences are visible, where composite beam \# 3 globally showed much lower initial stiffness in this range. This may also be deduced from graph presented in Figs. 10-11 when analyzing the initial values of the displacements. The reason for this behavior of beam \# 3 can be described in point 2 inhomogeneities found in the wood structure on a larger scale. 


\section{Summary}

The conducted research gives the opportunity to broaden the knowledge on creeping processes of composite wooden and concrete constructions. The obtained results still require numerous analyzes and the performance of computer simulations allowing for posing satisfying inverse problems in order to indicate the parameters, that will also determine the moisture-induced shrinkage and swelling of wood in relation to the rheology of layers, as well as inter-layer joint of the analyzed type of beams. It is also planned to continue the presented research until the displacements in composite elements have been determined in relation to particular seasons.

A sincere thank you to Adamietz Sp. z o.o., and in particular President Rajmund Adamietz for equipping the test stand with steel elements, as well as the Fałkopol company and its owner, Waldemar Cieplik, for the transfer of tanks used to load the structure.

\section{References}

1. M. Czabak, Z. Perkowski, K. Gozarska, B. Jędraszak, Badania zmian sztywności belki zespolonej drewniano-betonowej, Inżynieria i Budownictwo, 11 (2016) 604-608

2. M. Czabak, Z. Perkowski, Określanie podatności na ścinanie złącz w stropach zespolonych drewniano-betonowych przy wykorzystaniu pomiarów drgań, Wybrane zagadnienia inżynierii środowiska w budownictwie, PZITB O/Opole, Opole-Pruszków, (2014) 291-302

3. J. Natterer, J. Hamm, P. Favre, Composite wood-concrete floors for multistory buildings, Proceedings of the International Wood Engineering Conference, 3 (1996) 3431-3435

4. D. Yeoh, M. Fragiacomo, A. Buchanan, C. Gerber, Preliminary research towards a semiprefabricated LVL-concrete composite floor system for the Australasian market, Australian Journal of Structural Engineering, 9, 3 (2009) 225-240

5. D. Yeoh, K. H. Boon, L.Y. Loon, Timber-concrete composite floor beams under 4 years long-term load, International Journal of Integrated Engineering, 5, 2 (2013) 1-7

6. A. Ceccotti, M. Fragiacomo, S. Giordano, Long-term and collapse tests on a timberconcrete composite beam with glued-in connection, Materials and Structures, 40, 1 (2007) 15-25

7. M. Fragiacomo, E. Lukaszewska, Time-dependent behaviour of timber-concrete composite floors with prefabricated concrete slabs, Engineering Structures, 52, (2013) 687-696

8. E. Bou Saïd, J. F. Jullien, A. Ceccotti, Long term modelling of timber-concrete composite structures in variable climates, 8th WCTE, Lahti, Finland (2004)

9. A.M. Neville, Properties of concrete, Prentice Hall (2012)

10. M. Czabak, Model matematyczny zespolonej belki drewniano-betonowej w ujęciu liniowej lepko-sprężystości, XVIII KNDWB, Gliwice-Wisła (2018) (to be published)

11. A.N. Foulger, Classroom demonstrations of wood properties, Washington, U.S. Govt. Print. Off., Washington, 1969.

12. J.S. Popovics, J. Zemajtis, I.A. Shkolnik, Study of static and dynamic modulus of elasticity of concrete, ACI-CRC Final Report (2008).

13. Z. Perkowski Z., M. Czabak: Diagnostyka złącza międzywarstwowego belek zespolonych na podstawie analizy częstotliwości drgań własnych, Współczesna mechanika konstrukcji w projektowaniu inżynierskim, PAN KILiW, Warszawa (2015) 281-298 